DOI: http://doi.org/10.21698/simi.2018.fp50

\title{
ORGANIZATION OF HYDROGEOLOGICAL MONITORING WITHIN THE UKRAINIAN PART OF THE TISZA RIVER BASIN
}

\author{
$\underline{\text { Lidiia Davybida }}$
}

\author{
Department of Geotechnogenic Safety and Geoinformatics, Ivano-Frankivsk National \\ Technical University of Oil and Gas, Karpatska 15, Ivano-Frankivsk, 76000, \\ davybida61085@gmail.com, Ukraine
}

\begin{abstract}
The Ukrainian part of the sub-basin of Tisza, the largest left tributary of the Danube, which is located within five countries (Romania, Hungary, Slovakia, Ukraine, Serbia), is considered. This area due to the interaction of a number of natural and man-made factors is characterized by high risk of natural phenomena occurrence, particularly, floods, mudflows and landslides. There is a negative tendency in Ukraine to reduce the hydrogeological observation network. Obviously, that for the study area, further development of the monitoring system (restoration of stopped wells and construction of new wells) is expedient. In a geoinformation environment, a single monitoring geodatabase was created, that allowed maximum consideration of the results of hydrogeological surveys, ensured integration heterogeneous data and their overlay analysis, provided opportunities for effective design and optimization of the observation network based on the hydrogeological, analytical and statistical criteria.
\end{abstract}

Keywords: catchment area, groundwater, geodatabase, wells

\section{Introduction}

In recent decades Ukrainian hydrogeological observation network was extremely reduced due to insufficient financing. Thus, in 2014, monitoring of groundwater levels was carried out only at 350 hydrogeological monitoring wells and research on the chemical composition of water was not carried out at all. This situation is critical, especially given the fact that in the early 90's the state network of hydrogeological monitoring had 7,000 wells, the absolute majority of which are stopped or abandoned at all now (Shestopalov \& Lyuta 2016). As result, the longterm series of continuous observations are lost, which makes impossible the implementation of reasonable estimates and predictions of dynamic hydrogeological processes. Obviously, it is necessary to develop urgent measures for the restoration of the observation network and its gradual harmonized to European norms and requirements. It should be noted that one of the main principles of water management in most developed countries is monitoring and territorial management at a river basin (catchment area) level instead of an administrative territory. Basin principle of management is based on the unity of surface water and groundwater within the river basin. Particular attention is paid to transboundary catchment areas, located on the territory of several countries (Berezko \& Vasneva, 2012, Davybida \& Kuzmenko 2018, EUR-Lex Access 2018). 


\section{INTERNATIONAL SYMPOSIUM "THE ENVIRONMENT AND THE INDUSTRY", SIMI 2018, PROCEEDINGS BOOK}

\section{Materials and Methods}

The $8 \%$ of the catchment area of Tisza, the largest left tributary of the Danube, account for the territory of Ukraine, namely, the upper part of the basin on the southwestern slopes of the Ukrainian Carpathians and the Trans Carpathian lowland. The Ukrainian part of the Tisza basin is located within the Alpine folded structure of the Carpathians and covers the central part of the Ukrainian segment of the folded Carpathians and the Trans Carpathian Trench. The Ukrainian Carpathians are a complex hydrodynamic system where the Carpathian and Trans Carpathian basins of underground waters are distinguished by geostructural features and conditions for the formation, accumulation and circulation of groundwater (Basin Department of Water Resources of the Tisza River 2018).

In the framework of international cooperation within the territory of the Tisza catchment area, a flood control complex has been implemented, a monitoring system of the dynamics and quality for surface water has been established, using automated hydrogeological posts and a river basin management plan has been developed.

However, if one considers the measures for monitoring groundwater, it is necessary to note their recommend and declarative character. Thus, the boundaries of the allocated transboundary groundwater bodies (presented in Table 1) are still not coordinated with neighboring countries, the planned extension of the monitoring network at the border areas is not implemented. Moreover, according to official data of State Scientific and Production Enterprise "Geoinform of Ukraine” there was a significant reduction in the number of hydrogeological monitoring wells of the state network level (from 56 wells in 2010 to 6 wells in 2016), that is shown in Figure 1. Under the conditions of limited funding, an important task is the development of an effective strategy for reforming the system of hydrogeological observations.

The analysis of the accumulated research experience allows distinguishing two main approaches to the organization of hydrogeological monitoring networks. The first is based on the formal statistical estimation of the density of observation points, taking into account the given error of extrapolation of the studied parameters. The second is based on the assessment of conditions and factors for the groundwater formation and their regime, zoning of the territory taking into account different principles and the placement of regime monitoring points within typical areas. Using modern techniques (GIS) that allows effective combining of these approaches, operatively testing and evaluating various variants of the monitoring network within any territorial units (Davybida \& Kuzmenko, 2018).

Also, it should be noted that the European Union Water Framework Directive provides only a platform and recommendations for managing transboundary water resources. When the boundaries of groundwater bodies for Ukrainian transboundary territories is being defined and substantiated and the optimal monitoring network is being organized, both the experience of European countries and existing national scientific and practical results in the field of hydrogeological research of the territories should be taken into account, as well as the features of recharge, movement and unloading of natural groundwater, which are determined by the geological, physical-geographical conditions and the level of anthropogenic pressure within a particular territory (Koshliakov et al 2017). 
Table 1. Groundwater identified bodies within Ukrainian part of Tisza river basin (ICPDR 2018)

\begin{tabular}{|c|c|c|c|c|c|}
\hline Groundwater body & Age & ID & $\begin{array}{c}\text { Area within } \\
\text { Ukraine }\left(\mathrm{km}^{2}\right)\end{array}$ & Distribution & Type of use \\
\hline $\begin{array}{c}\text { Aquifer Middle } \\
\text { Pleistocene and } \\
\text { Quaternary Alluvial, } \\
\text { Lacustrine-Alluvial } \\
\text { Deposits }\end{array}$ & $\begin{array}{l}\left(\mathrm{a}, \mathrm{laP}_{\mathrm{II}-}\right. \\
\mathrm{III}+\mathrm{aH})\end{array}$ & $\begin{array}{c}\text { UA_TIS } \\
\text { GW_4 }\end{array}$ & 3883 & $\begin{array}{c}\text { Transboundary } \\
\text { distribution } \\
\text { (Romania, } \\
\text { Hungary, } \\
\text { Slovakia) }\end{array}$ & $\begin{array}{c}\text { Household } \\
\text { and drinking } \\
\text { water supply; } \\
\text { Agriculture }\end{array}$ \\
\hline $\begin{array}{l}\text { Aquarium complex } \\
\text { of lake-alluvial } \\
\text { deposits of Chop } \\
\text { suite and alluvium of } \\
\text { high terraces }\end{array}$ & $\begin{array}{c}(\mathrm{aE}- \\
\left.\mathrm{laE}+\mathrm{P}_{1} \mathrm{c} p\right)\end{array}$ & $\begin{array}{l}\text { UA_TIS } \\
\text { GW_204 }\end{array}$ & 1302 & $\begin{array}{l}\text { Transboundary } \\
\text { distribution } \\
\text { (Hungary, } \\
\text { Slovakia) }\end{array}$ & $\begin{array}{c}\text { Household } \\
\text { and drinking } \\
\text { water supply; } \\
\text { Agriculture }\end{array}$ \\
\hline $\begin{array}{l}\text { Aquarium complex } \\
\text { in the fracture zone } \\
\text { of Upper Miocene- } \\
\text { Pliocene } \\
\text { volcanogenic } \\
\text { formations }\end{array}$ & $\begin{array}{c}(\alpha \beta, \alpha, l- \\
\left.\mathrm{aN}_{1-2}\right)\end{array}$ & $\begin{array}{l}\text { UA_TIS } \\
\text { GW_220 }\end{array}$ & 1816 & Within Ukraine & $\begin{array}{c}\text { Household } \\
\text { and drinking } \\
\text { water supply; } \\
\text { Agriculture; } \\
\text { Balneology }\end{array}$ \\
\hline $\begin{array}{l}\text { Aquarium complex } \\
\text { in Upper Miocene- } \\
\text { Pliocene sediments }\end{array}$ & $\left(\mathrm{N}_{1-2}\right)$ & $\begin{array}{l}\text { UA_TIS } \\
\text { GW_240 }\end{array}$ & 1788 & $\begin{array}{l}\text { Transboundary } \\
\text { distribution } \\
\text { (Romania, } \\
\text { Slovakia) }\end{array}$ & $\begin{array}{c}\text { Household } \\
\text { and drinking } \\
\text { water supply; } \\
\text { Agriculture; } \\
\text { Balneology }\end{array}$ \\
\hline $\begin{array}{c}\text { Local-aquifer } \\
\text { complex in the } \\
\text { deposits of the } \\
\text { Sarmatian regional } \\
\text { tier }\end{array}$ & $\left(\mathrm{N}_{1 \mathrm{~s}}\right)$ & $\begin{array}{l}\text { UA_TIS } \\
\text { GW_263 }\end{array}$ & 3638 & $\begin{array}{c}\text { Transboundary } \\
\text { distribution } \\
\text { (Romania, } \\
\text { Hungary, } \\
\text { Slovakia) }\end{array}$ & $\begin{array}{c}\text { Household } \\
\text { and drinking } \\
\text { water supply; } \\
\text { Industry; } \\
\text { Balneology }\end{array}$ \\
\hline $\begin{array}{l}\text { Local-aquifer } \\
\text { complex in the } \\
\text { deposits of the } \\
\text { Baden regional tier }\end{array}$ & $\left(\mathrm{N}_{1 \mathrm{~b}}\right)$ & $\begin{array}{l}\text { UA_TIS } \\
\text { GW_283 }\end{array}$ & 4769 & $\begin{array}{c}\text { Transboundary } \\
\text { distribution } \\
\text { (Romania, } \\
\text { Hungary, } \\
\text { Slovakia) }\end{array}$ & $\begin{array}{c}\text { Household } \\
\text { and drinking } \\
\text { water supply; } \\
\text { Balneology }\end{array}$ \\
\hline $\begin{array}{c}\text { Local-aquifer } \\
\text { complex in the } \\
\text { Paleogene deposits }\end{array}$ & (P) & $\begin{array}{l}\text { UA_TIS_- } \\
\text { GW_300 }\end{array}$ & 2842 & Within Ukraine & $\begin{array}{c}\text { Household } \\
\text { and drinking } \\
\text { water supply; } \\
\text { Balneology }\end{array}$ \\
\hline $\begin{array}{c}\text { Local-aquifer } \\
\text { complex in the } \\
\text { Chalk and Paleogene } \\
\text { deposits }\end{array}$ & $(\mathrm{K}+\mathrm{P})$ & $\begin{array}{l}\text { UA_TIS } \\
\text { GW_425 }\end{array}$ & 4241 & Within Ukraine & $\begin{array}{c}\text { Household } \\
\text { and drinking } \\
\text { water supply; } \\
\text { Industry; } \\
\text { Balneology }\end{array}$ \\
\hline
\end{tabular}




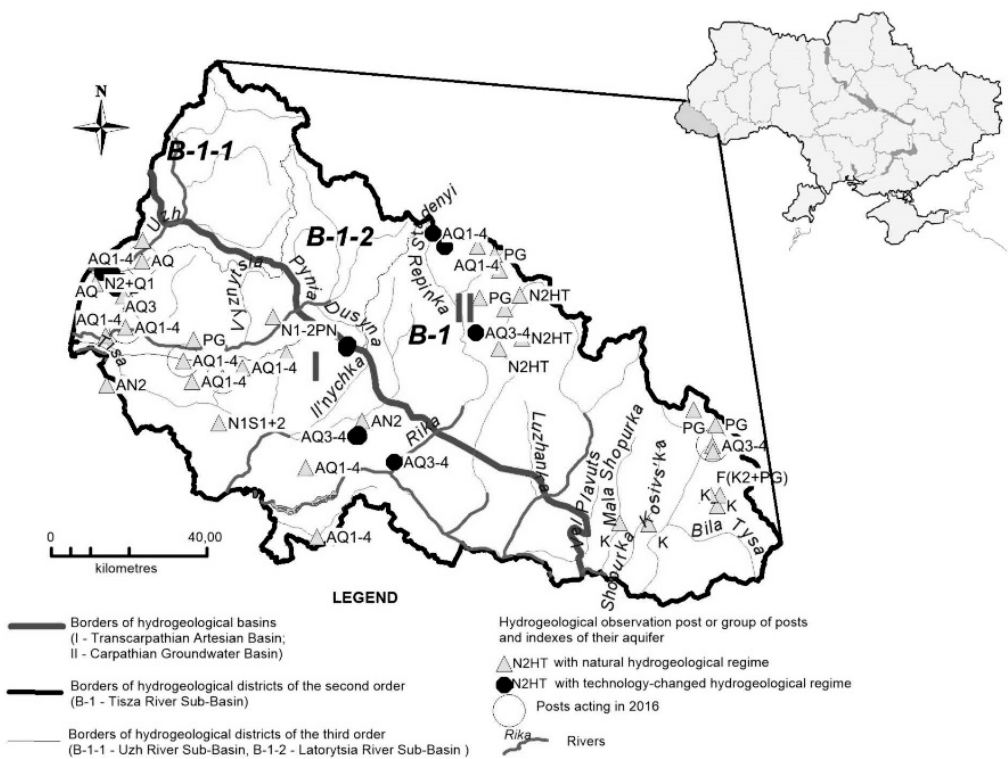

Figure 1. The studied area and state hydrogeological monitoring network

\section{Results and Discussion}

In a geoinformation environment, which includes general and special geospatial information, a single geodatabase was created. The significant part of the database is the layers of hydrogeological zoning according different approaches. The complex geological structure of the studied area has caused a great variety of its hydrogeological conditions, which are unequal for the groundwater using and its vulnerability to the industrial pollution. The hydrogeological areas identified by various principles are considered as a territorial basis to conduct the groundwater monitoring as well as projecting and improvement of the current network of observation wells. In this paper, the zoning scheme based on groundwater formation conditions as well as the scheme of functional zoning pursuant to the basin principle are chosen as the initial cartographic materials that characterize conditions creating the regime on the area.

The zoning scheme of the groundwater formation is based in accordance with the geological and structural principle of hydrogeological zoning, which takes into account the heterogeneity of the earth's crust composition and structure. The regions, which are covering the largest geo-structural units - the hydrogeological massifs as well as artesian basins, are allocated at the core of the scheme. There are smaller taxonomic units that include the hydrogeological areas representing a part of the groundwater basin expressed on the certain territory, which is characterized by a specific combination of geological structure, relief, climatic, hydrological and, eventually, hydrogeological conditions. The smallest taxonomic units of typing, which characterize the stratigraphic features of the conditions for the groundwater formation in the profile, are the landscape hydrogeological complexes, which 


\section{INTERNATIONAL SYMPOSIUM "THE ENVIRONMENT AND THE INDUSTRY", SIMI 2018, PROCEEDINGS BOOK}

includes separate areas, where the first water bearing horizon is deposited having the defined stratigraphic sections, reflecting the structure of the aerated zone, waterbearing and waterproof layers and, to certain extent, stipulate peculiarities of the groundwater recharge and discharge as well as the reservoir properties of the upper layer of rocks where their formation takes place. (LHC) are azonal units of zoning and they are characterized by common features of the most hydrogeological areas, mainly within the groundwater basins. In general, 26 varieties of plain LHC and 6 varieties of mountainous LHC are identified in Ukraine. There are 10 varieties (4 plain LHC and 6 mountainous LHC) within the Ukrainian part of the Tisza basin (Ruban \& Nikolishina 2005).

The functional zoning scheme according to the basin principle (under conditions of water exchange in the upper hydrogeological layer, shown in Figure 1) may be considered as the basic one for reorganization of the state system for the groundwater monitoring, in accordance with the principles of the EU Water Framework Directive. The system for studying of the groundwater drainage is based on the dynamic features of objects allocated according to the principle of groundwater runoff unity from the areas of drainage formation to its main discharge, which is controlled by a single closed balance of the groundwater. Within the hydrogeological structures, one may allocate water exchange basins of the first order, which are characterized by single or close trends of the regional water exchange. The hierarchy of this zoning is as follows: there are basins of sea drainage (regions) and main rivers that flowing into the seas (provinces). The next zoning level takes into account peculiarities of the hydrogeological conditions as well as the close trends of lateral water exchange, thanks to that, the basins of rivers' groundwater flow are united within the bounds of the single zoning units (provinces), where the subareas corresponding to water exchange basins of different main rivers tributaries are allocated. The water exchange basins, sizes and boundaries of which are determined by sizes and configuration of the river basins as a rule, should be considered as characteristic systems with homogenous regime in forecasting changes in level of the ground water, that is a part of underground hydrosphere the most closely related to the external surface factors forming the groundwater recharge and discharge. The expediency of monitoring study for both surface and underground water is also confirmed by synchronicity of the long-term variability of the mid-annual surface water flow and the annual average depth of the groundwater level (Davybida \& Kuzmenko 2018).

The studied territory belongs to the hydrogeological province of the Danube River, which coincides territorially with the hydrogeological district of the Tisza River (B1) within the studied region. The hydrogeological district includes two sub-districts -B-1-1 (the Uzh River) and B-1-2 (the Latorytsia River).

In order to integrate the spatial data, the spatial binding of raster maps was conducted and they were transferred into the vector format by digitalization.

It has been created geodatabase that includes the following layers with the relevant attributes: hydrogeological monitoring stations (code, number, type, depth, coordinates $\mathrm{X}$ and $\mathrm{Y}$, type of water-bearing horizon, regime type, disturbance of regime); levels of groundwater surface (code, level); contours of distribution of groundwater bodies (code, type, international index, geological age, distribution, area within Ukraine, type of use); hydrogeological provinces (code, index, water exchange basin); hydrological districts (code, index, water exchange basin); water- 


\section{INTERNATIONAL SYMPOSIUM "THE ENVIRONMENT AND THE INDUSTRY", SIMI 2018, PROCEEDINGS BOOK}

resource regions (code, index, departmental subordination); hydrogeological basins, allocated under the conditions of formation and groundwater occurrence (code, index, basin); hydrogeological district (code, index, district); hydrogeological subdistrict (code, index, sub-district); landscape hydrogeological complexes (code, index, age of rocks of the aeration zone, rocks of the aeration zone, chemical composition of the aeration zone, limit values of aeration zone depth, limit values peculiar to the coefficient of the aeration zone filtration, age of rocks contained in the water-bearing formation; rocks of the water-bearing formation; chemical composition of waters contained in the ground water-bearing horizon, limit values peculiar to the filtration coefficient of water-bearing horizon, age of watercourse rocks, filtration coefficient of watercourse rocks, limit values of mineralization, water hardness and $\mathrm{pH}$ index); additional information layers of hydrological and meteorological points; vector layers of the basic information including administrative boundaries, settlements, roads, rivers, vegetation, relief.

Results of long-term regime observations over the groundwater levels, presented in the form of average monthly values of groundwater depth levels calculated under the data of timing observations, as well as results of observations on the variability of annual surface water discharge, weather and climate characteristics (average annual air temperature, amount of precipitation), long-term change of numerical characteristics peculiar to the geological features (the energy of earthquakes) and the cosmogenic features (solar activity) required to form the hydrogeological regime.

Results of the routine dynamics observations are stored in the external relational database and can be attached to the spatial objects (meteorological, hydrological and hydrogeological monitoring stations) using unique codes of the supervisory stations. The development of the network of hydrogeological monitoring for the studied area should be carried out in compliance with the following basic principles: maximum possible preservation and restoration of monitoring wells that functioned earlier; congestion of the network (first of all, in the border zones); the involvement of sources and household wells as observation points; taking into account hydroisobath maps for designing of the quantitative monitoring network and maps of landscaping and hydrogeological complexes for the qualitative monitoring network; estimation of an expected accuracy of hydrogeological models for the projected network; carrying out optimization of the hydrogeological monitoring network and clarification of groundwater bodies boundaries after 2-3 years of the observation period, using analytical or geostatistical criteria (Ben-Jema et al 1994, Hudak \& Loaiciga 1992).

Obviously, that the number of hydrogeological monitoring points should be increased for the Ukrainian part of the sub-basin of Tisza. Thus, not only for groundwater bodies, but also for each hydrogeological district, allocated on the hydro geodynamic principle within the water exchange basins of the Dniester and the Danube, it is necessary to position the posts in such a way that they would be representative on the river, terrace and watershed types of groundwater regime. Another criteria for choosing the location of the observation point is the distribution of LHC. Such placement of monitoring points will enable to capture observations of the areas with different conditions of the hydrogeological regime formation and to obtain more complete information about the spatial and temporal variability of the groundwater regime elements. 


\section{INTERNATIONAL SYMPOSIUM "THE ENVIRONMENT AND THE INDUSTRY", SIMI 2018, PROCEEDINGS BOOK}

\section{Conclusions}

Consequently, the basic current network of the state hydrogeological monitoring within the studied area, which in 2016 included only 6 observation wells, does not fulfilled assigned functions and it requires serious reorganization. The observation network and the monitoring program for the Ukrainian part of the sub-basin of Tisza should be developed on the basis of a comprehensive analysis of the hydrogeological conditions and the results of observations on elements of the hydrogeological regime using geoinformation systems and technologies. It should also be taken into account that the cost of any measures to improve groundwater status is much higher than the cost of optimizing the monitoring system.

\section{Acknowledgements}

This work would not have been possible without the information support of the State Scientific and Production Enterprise "Geoinform of Ukraine". I am especially thankful to the employees of the Department of Accounting of Groundwater Resources, who worked to provide the research with actual hydrogeological monitoring data.

\section{References}

Basin Department of Water Resources of the Tisza River 2018, National Tisza River Basin Management Plan, 04 July 2018, State Agency of Water Resources of Ukraine. Available from: http://buvrtysa.gov.ua/ newsite/download/ National\%20plan\%20final_ost.pdf. [04 July 2018].

Ben-Jema, F, Marino, M \& Loaiciga, H 1994 'Multivariate geostatistical design of groundwater monitoring networks 'Journal of water resources planning and management-ASCE, vol. 120, pp. 505-522.

Berezko, O \& Vasneva, O 2012 'Groundwater monitoring in Belarus: implication and future prospects. Transboundary Aquifers in the Eastern Borders of the European Union', Springer Science+Business Media, Dordrecht.

Davybida, L \& Kuzmenko, E 2018, 'Assessment of observation network and state of exploration as to groundwater dynamics within Ukrainian hydrogeological province of Dnieper river', Geomatics and Environmental Engineering, vol. 12, no. 2, pp. 19-31.

EUR-Lex Access to European Union law, 2018, Directive 2000/60/EC of the European Parliament and of the Council of 23 October 2000 establishing a framework for Community action in the field of water policy, 04 July 2018,

The European Union. Available from: http://eurlex.europa.eu/resource.html?uri=cellar:5c835afb-2ec6-4577-bdf8

756d3d694eeb.0004.02/DOC_1\&format=PDF. [04 July 2018].

Hudak, P \& Loaiciga H 1992, 'A location modeling approach for groundwater monitoring network augmentation', Water Resources Research, vol. 28, pp. 643-649.

ICPDR, 2018, Integrated Tisza River Basin Management Plan, 04 July 2018, The International Commission for the Protection of the Danube River. Available from:https://www.icpdr.org/main/sites/default/files/Uploaded\%20\%20ITRBM \%20PLan\%20-\%20Jan\%202011_V2GWcomprev\%20Okt2011.pdf. [04 July 2018].

Koshliakov, O, Dyniak, O \& Koshliakova, I 2017, 'Problems of determination of groundwater body at cross-border regions of Ukraine according to EU water 
legislation', Visnyk of Taras Shevchenko National University of Kyiv: Geology, vol. 79, no. 4, pp. 67-70.

Ruban, S \& Nikolishina, A 2005 Groundwater of Ukraine, Dnipropetrovsk.

Shestopalov, V \& Lyuta, N 2016 'Status and ways of reforming the state groundwater monitoring system accounting international experience and requirements of the European Union Water Framework Directive', Mineral'ni resursy Ukrayiny, no. 2, pp. 3-4. 